\title{
Konsep Pendekatan Behavior dalam Menangani Perilaku Indisipliner pada Siswa Korban Perceraian
}

\author{
Muchamad Agus Slamet Wahyudi \\ Mahasiswa BKI Pascasarjana UIN Sunan Kalijaga Yogyakarta \\ Diterima: Maret 2017. Disetujui: Mei 2017. Dipublikasikan: Juni 2017
}

\begin{abstract}
This research implies the concept of behavioral approach in dealing with insdisciplinary behavior in student of divorce victim. Behavior itself is one of the guidance in guidance and counseling to overcome maladaptife behavior toward adaptive. Behavioral approach is the right approach to handle undisciplined students in school. So that students are able to perform their duties well in school, without experiencing obstacles. This undisciplined behavior is influenced by one of the factors of internal student problems, which tend to be from a student's background due to a divorce. The research method using qualitative descriptive approach by emphasizing on direct plunge. Furthermore, if the assessment has been done, then the planning can be implemented to the counseling process. Started contract counseling, relaxation, modeling, reward and punisment until the follow-up phase.
\end{abstract}

Keywords: Behavior; Student; discipline; divorce

\begin{abstract}
Abstrak: Penelitian ini memapakan konsep pendekatan behavior dalam menangani perilaku insdisipliner pada siswa korban perceraian. Behavior sendiri merupakan salah satu pendekaan dalam bimbingan dan konseling untuk mengatasi perilaku maladaptife menuju ke adaptif. Pendekatan behavior merupakan pendekatan yang tepat guna menangani siswa yang tidak disiplin di sekolah. Agar siswa mampu menjalankan tugasnya dengan baik di sekolah, tanpa mengalami hambatan. Perilaku tidak disiplin ini dipengaruhi salah satu faktor yaitu masalah-masalah dari internal siswa, yang cenderung dari latar belakang siswa akibat perceraian. Metode penelitian dengan menggunakan endekatan deskriptif kualitatif dengan menekankan pada terjun langsung kelapangan. Selanjutnya apabila assessment sudah dilakukan, maka perencanaan dapat dilaksanakan ke proses konseling. Dimulai kontrak konseling, rileksasi, modeling, reward dan punisment sampai tahap follow up.
\end{abstract}

Kata Kunci : Behavior; Indisipliner; siswa; perceraian

\section{Pendahuluan}

Sekolah merupakan tempat menimba ilmu bagi para pelajar untuk mewujudkan salah satu poin kehidupan yaitu cita-cita. Dengan mengenyam bangku sekolah dapat meningkatkan kualitas pengetahuan yang lebih terarah serta terkonsep secara sistematis melalui bimbingan bapak dan ibu guru yang mengajar. Sekolah mengembangkan dua potensi setiap para peserta didiknya, baik secara prestasi akademik maupun non akademik, namun yang lebih ditekankan bahwa sekolah sumber transformasi peletakan akhlak bagi siswa-siswi. Hal ini senada dengan misi Nabi Muhammad sang Rasulullah yang diutus dimuka bumi ini untuk menata perilaku umat manusia, dari model perilaku yang jahiliyah menuju masyarakat yang madani.

Sekolah mempunyai elemen penting untuk menunjang berjalannya mobilitas sekolah, diantaranya Guru atau disebut tenaga pendidik, Siswa atau yang dikenal sebagai peserta didik, staf sekolah dan masih banyak lainnya.

Guru dan Siswa adalah unsur yang tidak bias dilepaskan, sangat mustahil bila sekolah hanya ada guru namun tidak ada siswa, begitu sebaliknya. Dua komponen ini harus dijadikan satu wadah secara utuh agar terciptanya suatu proses transfer of knowledge. Ada pemateri, ada yang diberi materi, ada penata materi. 
Membicarakan siswa di Sekolah sangatlah menarik, baik dari segi positif semisal prestasi dan keteladanan siswa juga banyak, namun ada juga yang dari segi negatif juga amatlah banyak. Oleh sebab itu kajian mengenai siswa, terlebih akan perilakunya di sekolah sangatlah menarik untuk dikupas lebih mendalan. Dan saya jamin tidak akan pernah habis untuk dikaji secara mendalam.

Dalam dunia pendidikan teramat wajar apabila siswa mampu berperilaku dengan baik dengan menjalani aturan sekolah yang telah ditentukan, karena sekolah merupakan salah satu jembatan perubahan menuju yang lebih baik. Namun apabila ada siswa yang mengalami kesulitan dalam mengikuti aturan, atau dalam bahasa sehari-hari sering disebut siswa yang tidak disiplin atau siswa yang kurang mampu menaati peraturan yang dibuat oleh sekolah, maka siswa akan terkena sanksi disiplin yang sudah diatur dalam tata tertib sekolah. Hal ini membuat ritme kegiatan sekolah siswa menjadi terganggu. Penyesuaian terhadap kondisi skolah yang mempunyai banyak peraturan sangatlah perlu. Bila siswa tidak mampu menaati peraturan yang berlaku maka akan ada penangan khusus dari sekolah melalui kesiswaan bahkan guru bimbingan dan konseling agar siswa dapat menjalani peraturan sebagaimana mestinya aturan yang berlaku. Penangan bagi siswa yang tidak disiplin ini bermacam-macam, mulai dari sanksi fisik, bahkan sanksi non fisik, atau pembinaan rutin sampai siswa benar - benar mampu mempunyai kebiasaan sebagaimana aturan yang berlaku. Dengan kata lain siswa disiplin dalam menaati peraturan sekolah.

Dahlan al Barry (1994 : 115) mengemukakan bahwa Disiplin sendiri mempunyai arti menaati tata tertib, ketaatan pada peraturan. Sedangkan Musrofi (2010: 3)mengartikan disiplin pada siswa adalah suatu keadaan tertib dan teratur yang dimiliki oleh peserta didik di sekolah, tanpa ada pelanggaran-pelanggaran yang merugikan baik secara langsung maupun tidak langsung terhadap peserta didik sendiri dan terhadap sekolah secara keseluruhan.

Beberapa siswa yang tidak disiplin atau melanggar peraturan itu bukan tanpa sebab, namun ada yang melatar belakangi. Hasil wawancara dengan guru BK SMP Diponegoro depok bahwa ada siswa yang tidak disiplin dari diri sendiri, misalnya malas, susah diatur, ada pula faktor dari luar, misalnya latar belakang dari keluarga broken home atau orang tua yang bercerai, ada pula orang tua yang sibuk dengan pekerjaannya dan masih banyak lagi. Namun dalam hal ini saya lebih tertarik untuk melihat siswa yang tidak disiplin dari faktor orang tua yang bercerai.

Ketertarikan saya dengan siswa tidak disiplin namun dilatar belakangi dari orang tua yang bercerai bukan tanpa sebab. Salah satu sebab saya tertarik adalah melihat kondisi siswa yang harus membagi dua fokus pada orang tua mereka sendiri, yang mana layaknya orang tua saling melengkapi untuk kasih sayang seorang ayah maupun ibu, namun mereka hanya mendapatkan kasih sayang dari salah satu orang tua mereka saja, entah itu hanya bapak, maupun ibu saja. Proses ini tentunya sangat menghambat, bahkan mengganggu proses pendidikan yang didapatkan siswa. Dukungan moril maupun materil seharusnya tercurahkan semua, namun mereka hanya mendapatkan satu dukungan saja. Ditambah kegiatan orang tua yang single parent harus siap bekerja ekstra, yaitu selain mendidik anak, orang tua juga harus mencari nafkah sendiri untuk mencukupi dia dan anak - anaknya. Hal inilah yang memicu anak, sering terabaikan, bilamana terlalu fokus bekerja, maka akan perhatian untuk anak berkurang.

Boedi Abdullah dan Beni Ahmad Saebani (2013 : 58) menuturkan perceraian sendiri mempunyai arti Putusnya pernikahan adalah perceraian. Dalam istilah hukum islam adalah thalaq, artinya melepaskan atau meninggalkan. kenakalan remaja yang disebabkan karena broken home maupun quasi broken home dapat diatasi dengan cara- cara tertentu. Dalam broken home cara mengatasi agar anak tidak menjadi delinquent ialah orang tua yang bertanggung jawab 
memelihara anaknya hendaklah mampu memberikan kasih sayang sepenuhnya sehingga anak tersebut merasa seolah-olah tidak pernah kehilangan ayah dan ibunya. Sudarsono (1995 : 126) menambahkan di samping itu keperluan anak secara jasmaniah (makan, minum, pakaian dan saran-sarana lainnya) harus dipenuhi pula sebagaimana layaknya sehingga anak tersebut terhindar dari perbuatan yang melawan hukum, misalnya pencurian, penggelapan, penipuan, dan delik-delik lain di luar KUH Pidana, misalnya penyalahgunaan obat-obat terlarang seperti narkotika.

Republika Online, pada Rabu, 16 maret 2016, 12.01 WIB ada Temuan mengejutkan dikabupaten sleman bahwa angka perceraian sangatlah meningkat. Seperti pernyataan Humas Pengadilan Agama sleman Marwoto dari Republika.co.id bahwa angka perceraian di Kabupaten Sleman meningkat dari tahun ke tahun, tercatat pada 2014 kasus perceraian yang masuk ke PA Slemanberjumlah 1.389 kejadian. Angka tersebut terdiri dari cerai talaksebanyak 402 dan cerai gugat 987 kasus. Sementara pada 2015jumlahnya meningkat menjadi 1.509 kasus. Angka tersebut terdiri dari cerai talak 464 dan cerai gugat 1.045 kasus. Sedangkan pada 2016 dari Januari hingga Februari kasus cerai yang masuk berjumlah 170 perkara. Sebanyak 59 merupakan cerai talak, dan sisanya cerai gugat. Marwoto menyampaikan, hal in tentu mengkhawatirkan kelangsungan rumah tangga.

Ini senada dengan pernyataan guru BK di salah satu SMP swasta di Sleman Yogyakarta, yaitu SMP Diponegoro Depok, Sleman, Yogyakarta, bahwa beberapa siswa yang sering melanggar peraturan sekolah mereka adalah berlatar belakang dari orang tua yang bercerai. Data guru BK menyatakan ada sekitar 5 anak yang mendapat pantauan khusus dari guru BK untuk selalu didampingi dalam penangan ketidak disiplinan.

Sepertinya benang merah antara siswa, sekolah, rumah (orang tua) sangatlah berkaiatan. Ketika rumah merupakan pembelajaran menerapkan hidup dalam keseharian, sedangkan sekolah merupakan rumah kedua untuk pembelajaran teori, maka diperlukan satu kondisi yang nyaman antara rumah dan sekolah. Hal ini harus terpenuhi agar terwujudnya kenyamanan belajar yang komprehensif. Bila di sekolah diajarkan untuk sekolah, maka seyogyanya pada waktu dirumah, tugas orang tua mengaplikasikan apa yang telah diajarkan di sekolahnya.

Namun dampak perceraian yang dikemukakan saudari Isna Nur Khoeriyah dalam skripsi yang berjudul "Dampak Perceraian Orang Tua Terhadap Kondisi Mental Dan Motivasi Belajar PAI (Studi Kasus 3 Siswa Kelas Viii Mts Wahid Hasyim Yogyakarta)" menemukan bahwa dampak dari bercerai adalah anak menjadi Malas, Brutal dan melakukan tindakan yang tidak diinginkan. Oleh sebab itu perlu ada tindakan penangan layanan Bimbingan dan Konseling untuk menangani siswa yang mengalami ketidak disiplinan karena sebagai korban perceraian orang tua mereka sendiri. Anak yang orang tunya bercerai otomatis kasih sayangnya berkurang, maka dia terpicu untuk mencari kasih sayang dari kegiatan yang lain, yang tanpa ia sadari itu biasanya mengarah kepada hal - hal yang negatif. Hanya perhatian yang intensif dari orang tua ke anak, agar anak bisa berkembang secara optimal. Tidak mengarah pada kasih sayang yang negatif. Oleh karena itu perlu adanya penanganan khusus dalam pengubahan tingkah laku.

Gerald Corey (1988 : 196) Behavior merupakan salah satu pendekatan layanan bimbingan dan konseling yang berakar pada berbagai teori belajar. Penerapn prinsip-prinsip belajar pada pengubahan tingkah laku ke arah cara-cara yang lebih adaptif.

Penggunaan pendekatan Behavior terbukti efektif untuk mengurangi masalah siswa di sekolah. Seperti hasil karya ilmiah skripsi Indah Widuri Amalia yang berjudul Mengatasi Prokrastinasi Akademik Melalui Pendekatan Konseling Behavior Teknik Behavior Contract pada Siswa Kelas VIII E SMP Negeri 13 Semarang, yang mengatakan bahwa hasil penggunaan teknik 
behavior mampu mengurangi perilaku prokrastinasi siswa atau dengan bahasa lain siswa yang sulit mengerjakan sesuatu sesuai batas yang telah ditentukan, atau menunda-nunda pekerjaan mengalami penurunan dari yang sedang menjadi rendah, atau dengan angka sekitar 5\%.

Pada skripsi lain juga penggunaan teknik behavior sangatlah efektif dalam menangani tiga siswa yang membolos di sekolah, terbukti dengan adanya pemahaman siswa mengenai pentingnya sekolah serta mampu menolak ajakan teman untuk membolos sekolah.

Dalam jurnal paradigm yang ditulis Sigit Sanyata (2012 : 10-11) Behavioristik merupakan salah satu pendekatan teoritis dan praktis mengenai model pengubahan perilaku konseli dalam proses konseling dan psikoterapi. Pendekatan behavioristik yang memiliki ciri khas pada makna belajar, conditioning yang dirangkai dengan reinforcement menjadi pola efektif dalam mengubah perilaku konseli. Pandangan deterministik behavioristik merupakan elemen yang tidak dapat dihilangkan Pendekatan behavioristik menekankan pentingnya lingkungan dalam proses pembentukan perilaku. Pendekatan ini bertujuan untuk menghilangkan tingkah laku salah suai, tidak sekedar mengganti simptom yang dimanifestasikan dalam tingkah laku tertentu. Dengan pendekatan behavior, diharapkan konseli memiliki tingkah laku baru yang terbentuk melalui proses conditioning, hilangnya simptom dan mampu merespon terhadap stimulus yang dihadapi tanpa menimbulkan masalah baru.

Abdul Choliq Dahlan (2009: 1) Bimbingan dan Konseling merupakan salah satu media untuk memberikan layanan perbaikan diri. Istilah ini sudah tidak asing bagi kalangan generasi saat ini, alias generasi tahun duaribuan. Secara eksplisit istilah ini merupakan dua sejoli yang tidak bisa dipisahkan. Arah tjuan bimbingan dan konseling merupakan sejalan dengan tujuan islam yaitu untuk kemaslahatan. Seperti peuturan Aunur Rahim Faqih daam bukunya Abdul Choliq Dahlan bahwa bimbingan dan konseling Islami merupakan proses pemberian bantuan terhadap individu agar mampu hidup selaras dengan ketentuan dan petunjuk Allah sehingga dapat mencapai kebahagiaan hidup di dunia dan akhirat.

Gerald Corey (1988: 196) Behavior merupakan salah satu teknik guna merubah tingkah laku yang lebih adaptif. Pendekatan ini dirasa lebih efektif untuk menangani kasus-kasus dalam dunia pendidikan, khususnya maladaptive. Berfokus pada modifikasi tingkah laku menjadi ciri yang sangat menonjol dalam teknik behavior. Teknik ini berkembang mulai tahun 1950-an hingga sekarang, teknik behavior masih relevan untuk diterapkan.

Penting untuk diketahui bahwa behavior ini merupakan aspek gerakan memodifikasi tingkah laku pada taraf yang masih bias didefinisikan secara operasionanl, diamati dan diukur. Manusia mempunyai potensi positif dan negativ yang bias jadi terbentuk karena factor lingkungan social budaya.

Adapun ciri behavior dapat dilihat dari:

a. Pemusatan perhatian kepada tingkah laku yang tamapak

b. Kecermatan dan penguraian tujuan-tujuan treatment.

c. Perumusan prosedur treatment yang spesifik sesuai dengan masalah.

d. Penaksiran objektif atas hasil-hasil terapi.

Arah dari behavior dasarnya adalah mengarah pada perolehan tingkah laku baru yang lebih adaptif, sehingga dapat menghapus tingkah laku yang maladaptive. Serta tingkah laku dapat diasosiasikan dengan tingkah aku yang nampak, dan berpusat pada here and Now. Semua tingkah laku dapat dipelajari baik yang adaptif maupun yang maladaptive. Belajar merupakan cara efektif mengubah tingkah laku maladaptif.

Corey (1988: 212-220) menuturkan macam-macam teknik behavior antara lain:

a. Desensititasi sitematik 
Ini merupakan salah satu teknik paling luas dalam behavior. Desensititasi sitematik digunakan untuk menghapus tingkah laku yang diperkuat secara negatif, dengan menyertakan pemunculan tingkah laku yang hendak dihapuskan. Hal ini klien diarahkan untuk menampilkan suatu respon yang tidak konsisten dengan kecemasan. Wolpe dalam bukunya corey membagi prosedur desensitisasi pertama-analisis tigkah laku atas stimulus-stimulus yang bias membangkitkan kecemasan dalam suatu wilayah tertentu seperti penolakan, rasa iri. Kedua-lahatian relaksasi. Ketiga-membuat keadaan klien santai dengan mata tertutup.

b. Asertif

Klien belajar untuk membedakan tingkah laku agresif, pasif dan asertif. Tujuannya agar klien blajar bertingkah laku asertif.

c. Aversi

Tehnik ini untuk meredakan gangguan behavior yang spesifik. Agar tingkah laku sesuai yang diinginkan, maka stimulannya adalah berupa hukuan-hukuman.

d. Skedul penguatan

Memperkuat tingkah laku yang muncul. Maka stelah perilaku terbentuk, maka penguatan dikurangi, tambahan dari Jeanette Murad Lesmana (2005: 30)

e. Shapping

Tingkah laku yang dipelajari secara bertahap dengan pendekatan suksesif. Untuk itu konselor membagi secara terinci supaya klien dapat belajar dengan detail dan terici.

f. Teknik Relaksasi

Teknik yang digunakan untuk membantu konseli mengurangi ketegangan fisik dan mental dengan latihan pelemasan otot-ototnya dan pembayangan situasi yang menyenangkan saat pelemasan otot-ototnya sehingga tercapai kondisi rilek baik fisik dan mentalnya.

g. Teknik Flooding

Teknik yang digunakan konselor untuk membantu konseli mengatasi kecemasan dan ketakutan terhadap sesuatu hal dengan cara menghadapkan konseli tersebut dengan situasi yang menimbulkan kecemasan tersebut secara berulang-ulang sehingga berkurang kecamasannya teradap situasi tersebut.

h. Reinforcement Technique

Teknik yang digunakan konselor untuk membantu meningkatkan perilaku yang dikehendaki dengan cara memberikan penguatan terhadap perilaku tersebut.

i. Modelling

Teknik untuk memfasilitasi perubahan tingkah laku konseli dengan menggunakan model.

j. Cognitive restructuring

Teknik yang menekankan pengubahan pola pikiran, penalaran, sikap konseli yang tidak rasional menjadi rasional dan logis.

k. Self Management

Teknik yang dirancang untuk membantu konseli mengendalikan dan mengubah perilaku sendiri melalui pantau diri, kendali diri, dan ganjar diri.

1. Behavioral Rehearsal

Teknik penggunaan pengulangan atau latihan dengan tujuan agar konseli belajar ketrampilan antarpribadi yang efektif atau perilaku yang layak.

m. Kontrak 
Suatu kesepakatan tertulis atau lisan antara konselor dan konseli sebagai teknik untuk memfasilitasi pencapaian tujuan konseling. Teknik ini memberikan batasan, motivasi, insentif bagi pelaksanaan kontrak, dan tugas-tugas yang ditetapkan bagi konseli untuk dilaksanakan anatr pertemuan konseli.

n. Pekerjaan Rumah

Teknik yang digunakan dengan cara memberikan tugas / aktivitas yang dirancang agar dilakukan konseli antara pertemuan konseling seperti mencoba perilaku baru, meniru perilaku tertentu, atau membaca bahan bacaan yang relevan dengan maslah yang dihadapinya.

o. Extinction (Penghapusan)

Extinction (Penghapusan) adalah menghentikan reinforcement pada tingkah laku yang sebelumnya diberi reinforcement.

p. Punishment (Hukuman)

Hukuman (Punishment) merupakan intervensi operant-conditioning yang digunakan konselor untuk mengurangi tingkah laku yang tidak diinginkan.

q. Time-out

Time-out merupakan teknik menyisihkan peluang individu untuk mendapatkan penguatan positif.

Wingkel (1997: 399) melengkapi dengan beberapa rangkaian behavioristic dalam konseling, $\mathrm{ABC}$ (Antecedent-Behavior-Consequence). Antecedent adalah kejadian-kejadian yang mendahului behavior, sedangkan consequence adalah efek yang mengikuti atau berlangsung setellah behavior.

Ariesandi (2008: 230-231) mengutai sikap tidak disiplin merupakan lawan kata dari disiplin, disiplin sendiri didefinisikan oleh Ariesandi adalah proses melatih pikiran dan karakter anak secara bertahap sehingga menjadi seseorang yang memiliki kontrol diri dan berguna bagi masyarakat. Furqon (2010: 45-49) melihat cara penegakan disiplin melalui peningkatan Motivasi, pendidikan dan lahatian, kepemimpinan dan penegakan aturan.

Agus Wibowo (2012: 85-86) mengindikatorkan Kedisiplinan Peserta didik:

a. Masuk sekolah tepat waktu pada jam yang telah ditentukan oleh peraturan di sekolah.

b. Mengakhiri kegiatan belajar dan pulang sesuai jadwal yang ditentukan.

c. Menggunakan kelengkapan seragam sekolah sesuai peraturan.

d. Menjaga kerapian dan kebersihan pakaian sesuai dengan peraturan sekolah.

e. Apabila berhalangan hadir ke sekolah (tidak masuk sekolah), maka harus menyertakan surat pemberitahuan ke sekolah.

f. Mengikuti keseluruhan proses pembelajaran dengan baik dan aktif.

g. Mengikuti dan melaksanakan kegiatan ekstrakurikuler yang ditentukan di sekolahan.

h. Mengerjakan tugas yang diberikan guru.

i. Melaksanakan tugas piket kelas sesuai jadwal yang ditentukan.

j. Mengatur waktu belajar, Sulistyorin (2009: 109).

Dari indikator diatas, cukup mudah untuk mengkategorikan ketidak disiplinan. Cukup siswa melanggar salah satu dari poin indicator tersebut, maka siswa dapat dikatakan tidak disiplin.

\section{Perceraian}

Dalam keluarga pasti menginginkan yang terbaik untuk kehidupan dan kelangsungan mobilitas keluarga. namun terkadang ada juga ada kemungkinan yang itu biasanya diluar dugaan 
kita. seperti halnya perceraian. Boedi Abdullah \& Beni Ahmad Saebani (2013: 58) mengartikan perceraian adalah Putusnya pernikahan adalah perceraian. Dalam istilah hukum Islam disebut thalaq, artinya melepaskan atau meninggalkan.

Sangat bias dipastikan apabila anak yang seharusnya perlu pendampingan dari kedua orang tua, namun hal itu terbelah menjadi hanya ssatu orang tua, akan menjadikan dampak tersendiri bagi kondisi anak. Sedangkan umumnya seorang anak ada kedua orang tuanya.

M. Yusuf di Jurnal al Bayan mengatakan bahwa Perceraian sendiri mempunyai pengaruh yang sangat besar terhadap perkembangan Jiwa dan pendidikan anak, terutama anak usia Sekolah Dasar dan remaja. Diantaranya dapat menyebabkan anak bersikap pendiam dan rendah diri, nakal yang berlebihan, prestasi belajar rendah dan merasa kehilangan. Pada umumnya anakanak yang keluarganya bercerai ikut bersama ibunya, dan semua biaya hidupnya yang seharusnya menjadi tanggung jawab bapak tetapi menjadi tanggung jawab si ibu.

J. R. Raco (2010: 9) Adapun metode penelitian yang digunakan dalam penelitian ini adalah penelitian lapangan (field research), karena penulis terjun langsung kelapangan, terlibat dengan masyarakat setempat. Kata Andi Prastowo (2011: 203) gaya deskriptif kualitatif. Dengan terjun langsung mengamati guru BK dalam memberikan proses konseling serta wawancara mendalam yang langsung di ambil dari sumber primer yaitu guru BK langsung.

\section{Metode Penelitian}

Metode penelitian dengan menggunakan pendekatan deskriptif kualitatif dengan menekankan pada terjun langsung kelapangan. Selanjutnya apabila assessment sudah dilakukan, maka perencanaan dapat dilaksanakan ke proses konseling. Dimulai kontrak konseling, rileksasi, modeling, reward dan punisment sampai tahap follow up.

\section{Hasil dan Pembahasan}

Masalah yang dihadapai siswa adalah siswa tidak disiplin dalam kegiatan sehari-hari di sekolah. Dimulai sering datang terlambat, meninggalkan pelajaran tanpa izin dengan pergi ke kantin sekolah, terlebih setelah ke kantin mereka merokok. Ketidak disiplinan yang ditunjukkan lagi seperti sering mengeluarkan baju dan tidak shalat dhuha. Proses selanjutnya penyusunan tujuan konseling, dimulai dari mendiskusikan konsekuensi sang anak bila masih terus tidak disiplin maka akan membuat anak semakin terpuruk dalam pembelajaran.

Hasil dari penelitian ini adalah penurunan peilaku indisipliner pada siswa korban perceraian, dengan menggunakan konsep pendekatan behavior. Masalah yang dihadapai siswa adalah siswa tidak disiplin dalam kegiatan sehari-hari di sekolah. Dimulai sering datang terlambat, meninggalkan pelajaran tanpa izin dengan pergi ke kantin sekolah, terlebih setelah ke kantin mereka merokok. Ketidak disiplinan yang ditunjukkan lagi seperti sering mengeluarkan baju dan tidak shalat dhuha. Setelah dilakukan konseling, terdapat temuan bahwa siswa melakukan semua itu karena faktor kejenuhan dari rumah. Latar belakang siswa yang orang tuanya bercerai, sehingga siswa hanya single parent yaitu diasuh oleh ibu, sedangkan ibu bekerja untuk memenuhi kehidupan sehari-hari. Dengan kegiatan si ibu yang bekerja full time membuat kondisi fisik sang ibu menjadi lelah, ketika sang ibu lelah dan si anak melakukan kesalahan sedikit saja, maka membuat si ibu cepat marah, melampiaskan kekesalannya baik dengan katakata keras, maupun fisik.

Hal ini yang dirasakan anak dirumah tidak nyaman. Ketika di rumah tidak nyaman hanya dengan luapan kemarahan dan ditambah kegiatan sekolah yang sangat kompleks, maka anak menjadi jenus. Pemaparan anak ketika ketahuan merokok, pernyataan yang sangat 
mencengangkan adalah merokok merupakan luapan kejenuhan dalam hidupnya. Secara eksplisit si anak hanya ingin diperhatikan lebih mendalam. Lebih-lebih rasa kasih sayang orang tua kepada anak. Peru digaris bawahi bahwa hubungan anak dengan ibu secara material finansial sangatlah tercukupi untuk sang anak.

Proses selanjutnya penyusunan tujuan konseling, dimulai dari mendiskusikan konsekuensi sang anak bila masih terus tidak disiplin maka akan membuat anak semakin terpuruk dalam pembelajaran. Dilanjut mulai menyadarkan anak bahwa perilaku yang dilakukan itu akalah perilaku maladaptif. Dan hal yang diinginkan anak sebenarnya apa.

Menggali hambatan-hambatan anak, mengenai perilaku maladaptive dengan kordinasi dengan orang tua. Membuat planning dalam menanggulangi ketidak disiplinannya, dimulai dari hal-hal yang terkecil seperti datang tepat waktu, belajar fokus dikelas dan lain-lain. Penggunaan teknik dimulai dari membuat anak serileks mungkin. Dari mulai disuruh menghela nafas, dilanjutkan mengeluarkan nafas, ditambah disuruh memejamkan mata dengan posisi duduk yang sangat nyaman, dengan mengistrukan membayangkan apa yang dirasakan klien, dan membayangkan klien mendapatkan sesuatu yang menarik baginya.

Selanjutnya Modeling. Penggunaan teknik modeling ini diwujudkan dengan memberikan model keteladanan akhlak Rasulullah dan kedisiplinan dan kegigihan Rasullah. Kenapa menggunakan model Rasulullah atau Nabi Muhammad dirasa sesuai dengan sendi-sendi Islam. Rasulullah juga mempunyai perilaku yang sangat sempurna dalam hal sifat kebaikan. Dari mulai menghargai waktu dan cara berpakaian, bertutur kata dan bersikap. Serta konsep ini sejalan dengan pahala dan dosa, serta surge dan neraka. Dimulai dengan penugasan kepada anak dengan membaca buku tentang kepribadian akhlak Rasulullah, setelai selesai membaca, anak disuruh enulskan poit penting yang didapat setelah ia baca. Hal ini dimaksudkan selain mengubah tingkah laku, anak juga bisa latihan membaca, serta memahmi isi dari buku.

Pertama dari teknik ini yang perlu dilakukan adalah behavior Kontrak, semacam MOU atau kesepakatan antar konselor dan konseli, menyepakati untuk siap menjalani terapi behavior. Dalam bentuk hitam diatas putih. Agar kedepan apabila konseli diluar hal diinginkan bisa teratasi, ditambah untuk selalu mengangat satu kontrak yang harus disepakati, agar reward dan punishment nya bisa dijalankan tanapa ada paksaan, melainkan sesuai kesepakatan kontak. Tidak hanya itu bila konseling melanggar ada tindakan yang mengekang.

Reward apabila konseli dapat menjalankan tugasnya, berupa sangsi penghapusan Point pelanggaran siswa sebesar 2 point dan penghapusan hukuman tidak shalat sunnah 2 rakaat. Sedangkan punismentnya adalah diberikan poit pelanggaran sebanyak 5 point, shalat sunnah 8 rakaat dan hafalan surat-surat pendek Juz Amma. Bahakan akan ada reward berupa membelikan makanan di kantin (di traktir). Tujuan dari reward berup shalat dan hafalan Juz Amma adalah meletakkan sendi - sendi nafas islami dan melatih pribadi siswa untuk giat mengerjakan kewajibannya sebagai seorang muslim yang taat. Alur dari modeling dimulai dari memaparkan dari sebuah cerita tentang perilaku Rasulullah, yang selalu menjalankan shalat tepat waktu. Itu di kontekskan dengan kegitan berangkat sekolah harus tepat waktu bahkan lebih.

Modeling tahap kedua dengan memberikan video/film tentang perjuangan Rasulullah ketika kecil, asumsinya biar bisa belajar dari rasulullah ketika masa kecil beliau. Hal ini dirasa sangat tepat, karena masa kecil rasulullah bisa mandiri meskipun tanpa kedua orang tua. Berarti mendorong siswa agar tidak kecil hati, dengan analogi, Rasulullah dengan tanpa orang tua saja bisa sukses, seharusnya siswa juga mencohtoh Rasulullah. Mekanismenya adalah ketika anak sudah diperlihatkan film yang terkait tentang Rasulullah, maka si anak juga mencatap pesan apa 
atau inti dari film yang dilihat itu apa, dengan begitu anak tidak ahanya melihat namun merekam hasil yang ia lihat dengan tulisan.

Setelah langkah modeling diperlihatkan, maka siswa akan dilihat dari kegiatan berangkat sekolah pagi, apakah masih sering terlambat atau tidak. Sekali lagi pemantauannya menggunakan table jam ketepatan waktu, setiap datang kesekolah dicatat waktunya. Tidak perlu berlebihan, cukup memberikan sebuah form table kebaikan, yang indikatornya terkait pelanggaran yang pernah dilakukan namun tidak dilakukan lagi. Apabila siswa mampu menjalankan tugas dan tidak melanggar, maka akan di beri hadiah, berupa pengurangan hukuman. Dengan kata lain siswa mencatat kebaikan yang telah dilakukan.

Kedua dengan hukuman, hal ini sejalan dengan reward dan punismet di modeling, bila disiplin mendapat reward, maka bila melanggar mendapat punishment. Hal ini digunakan agar ada konsekuensi dalam setiap perbutan. Adapun hukuman hampir sama metode punismentnya adalah hafalan surat pendek dan melakukan shalat sunnah. Serta ditambah akan membayar uang seribu rupiah bila melanggar tiga kali berturut-turut. Hal ini dimaksudkan, agar uang yang didapat sebagai hukuman nantinya bila mendapat reward bisa digunakan.

Teknik ini akan dibuatkan tabel khusus untuk melihat indikator keberhasilan, dan dicatat secara terus menerus.

Sebenarnya saya lebih menekankan modeling kepada akhlak Rasulullah, agar siswa selain meneladani akhlak, juga dapat mencontok spiritual Islam lebih mendalam.

Tehnik selanjutnya adalah teknik pekerjaan rumah, hal ini dimaksudkan agar siswa mempunyai kegiatan yaitu belajar dirumah, sehingga konseli mempunyai kesibukan belajar dan tidak dialihkan kepada kegiatan negatifnya, seperti merokok dan nongkrong dengan temantemannya dimalam hari.

Indikatorya sederhana, setiap hari siswa mencatat hal apa saja yang di abaca, meskipun sedikit, waktu yang ditentukan belajar dirumah satu minggu pertama cukup 15 menit perhari. Harapan dengan membaca dan menulisnya, maka siswa mempunyai kesibukan belajarnya. Selain itu setiap hari ada dua surat pendek yang dihafalkan. Hal mengapa menggunakan hanya 15 menit, karena ekspektasinya mengarah kepada konsistensi belajar, bila 15 menit perhari berhasil, maka ditingkatkan menjadi 30 menit perhari belajarnya, namun bila kondisi masih belum menunjukkan progress, maka minggu berikutnya masih tetap 15 menit sampai dia bisa konsisten.

Namun bila sehari tidak belajar atau menulis hasil belajarnya, maka akan terkena sanksi shalat sunnah 8 rakaat.

Reinsforment dalam teknik ini adalah bila mana klien sukses menjalankan tugasnya, maka akan mendapatkan bintang satu, bintang ini nantinya bisa untuk menambah nilai mata pelajaran akhlak. Selain itu pula penguatan akan diberikan dalam bentuk pujian seperti "kamu bisa, kamu hebat, kamu baik". Terlebih dalam setiap kegiatan jika klien berhasil menjalankan, maka akan mendapatkan buku dan bolpoin bila mencapai waktu satu minggu.

Time-out tehnik akan dilakukan apabila konseli membolos sekolah dijam pelajaran, gambarannya jika siswa ketahuan membolos pada jam pelajaran efektif, maka konsekuensinya adalah membersihkan kamar mandi, dan itu dilakukan hingga perilakunya membolos dapat berhenti.

Disesi terakhir akan selalu mereview perilaku yang telah ditunjukkan, secara berkala dan setiap seminggu sekali. Pilihan rencana kedua melakukan teknik pembanjiran. Dimana klien apabila membolos akan diberikan hak sepuasnya agar membolos. Hal ini ditujukan membuat klien bosan. Selanjutnya guna menanggulangi merokok, klien diajak disatu ruangan untuk 
merokok dengan menyediakan beberapa puluh batang rokok dan merokoknya sampai sebanyak mungkin.

Evaluasi ini dilakukan tentunya memudahkan pemantauan dan sentralisasi dalam penanganan. Tabel yang telah disepakati di atas dengan indikator perilaku yang positif, tentunya membuat arah tujuan tentang penghapusan perilaku maladaptif lebih terlihat. Bila masih belm menunjukkan hasil yang signifkan, bisa dkonsultasikan ke psikolog anak, atau alih tangan kasuh kepada yang lebih detail.

\section{Simpulan dan Saran}

Behavior merupakan salah satu pendekatan bimbingan dan konseling yang berpusat pada tingkah laku. Tidak disiplin merupakan salah satu perilaku maladaptif yang ada disekolah. Perilaku siswa yang tidak disiplin perlu diubah menjadi perilaku disiplin yang lebih adaptif. Proses perubahan tingkah laku dapat dipakai dengan meneladani akhlak rasullulah. Tidak hanya akhlak, namun rasulullah merupakan manusia superior yang bias diteladani dari segi apapun, baik dari ibadah, ketaatan, kepasrahan, serta kegigihan. Seperti untuk mencontok sekolah tepat waktu, meneladani ketepatan rasulullah dam menjalankan shalat lima waktu. Teknik pekerjaan rumah yang bertujuan siswa dapat belajar dengan konsisten. Serta reinsforment yang dibangun adalah mendapatkan tambahan nilai pada pelajaran akhlak dan mendapatkan buku dan bolpoin setiap seminggu sekali bila tugasnya tuntas. Namun tidak dipungkiri perlu menggunakan teknik hukuman, agar siswa lebih bisa serius dan tanggung jawab dengan apa yang ia kerjakan. Reward dan punismet dalam konteks ini nantinya berdampak pada keterkaiatan daalam pemberian. Bila rewardnya mendapat gratis jajan dikantin, maka punismentnya berupa uang yang nantinya dapat digunakan untuk rewardnya, itupun melalui proses pelanggaran tiga kali berturut-turut. Adapun model reward dan punisment yang lain hampir sama, persilangan, bila menjalankan dapat subsidi shalat, bila melanggar ditambah shalat. Tentunya melalui tahapan kontrak diwal yang telah disepakati secara sadar.

\section{Daftar Pustaka}

Abdul Choliq Dahlan, Bimbingan dan Konseling Islami (Sejarah, Konsep dan pendekatannya), Yogyakarta: Pura Pustaka, 2009

Agus Wibowo, Pendidikan Karakter, Strategi membagun Karakter Bangsa Berperadapan, Yogjakarta: Pustaka Pelajar, 2012

Andi Prastowo Memahami Metode-Metode Penelitian: suatu tinjauan teoritis dan praktis, Yogyakarta: Ar-Ruzz Media, 2011.

Ariesandi, Rahasia Mendidik Anak Agar Sukses dan Bahagia, Tips dan Terpuji Melejitkan Potensi Optimal Anak, Jakarta: PT Gramedia Pustaka Utama, 2008.

Arsip Guru BK menganai pendampingan siswa yang melanggar peraturan. Jum'at, 1 September 2016.

Boedi Abdullah \& Beni Ahmad Saebani, Pernikahan dan Perceraian Keluarga Muslim, Bandung: Pustaka Setia, 2013

Boedi Abdullah dan Beni Ahmad Saebani, Pernikahan dan Perceraian Keluarga Muslim, Bandung: CV Pustaka Setia, 2013

Gerald Corey, Teori dan Praktek Konseling dan Psikoterapi, Bandung: Eresco, 1988), hlm. 196 
Indah Widuri Amalia, Mengatasi Prokrastinasi Akademik Melalui Pendekatan Konseling Behavior Teknik Behavior Contract pada Siswa Kelas VIII E SMP Negeri 13 Semarang, Skripsi, Fakultas Ilmu Pendidikan, Bimbingan dan Konseling, S1 Universitas Negeri Semarang.

Isna Nur Khoeriyah, Dampak Perceraian Orang Tua Terhadap Kondisi Mental Dan Motivasi Belajar Pai (Studi Kasus 3 Siswa Kelas Viii Mts Wahid Hasyim Yogyakarta), skripsi, fakltas tarbiyah dan keguruan.

J. R. Raco, Metode Penelitian Kualitatif Jenis, Karakteristik dan Kegunaannya, Jakarta: Grasindo, 2010.

Jeanette Murad Lesmana, Dasar-dasar Konseling, Jakarta: UI Press, 2005

M. Dahlan Al Barry, Kamus Ilmiah Populer, Surabaya: Arkola, 1994

M. Furqon Hidayatullah, Pendidikan Karakter: Membangun Peradaban Bangsa, Surakarta: Yuma Pressindo, 2010.

M. Musrofi, Melesatkan Prestasi Akademik Siswa, Cara Praktis Meningkatkan Prestasi Akademik Siswa Tanpa Kekerasan dan Tanpa Harus Menambah Jam Belajar, Yogyakarta: PT Pustaka Intan Madani, Anggota IKAPI, 2010.

M. Yusuf, MY. Dampak Perceraian Orang Tua Terhadap Anak, Jurnal Al-Bayan / VOL. 20, NO. 29, JANUARI - JUNI 2014.

Republika Online, Duh, Angka Perceraian di Sleman Meningkat, Rabu, 16 maret 2016, 12.01 WIB

Sigit Sanyata, Teori dan Aplikasi Pendekatan Behavioristik dalam Konseling, Jurnal Paradigma, No. 14 Th. VII, Juli 2012.

Sudarsono, Kenakalan Remaja, Jakarta: PT RINEKA CIPTA, 1995.

Sulistyorini, Menejemen Pendidikan Islam Konsep, Strategi dan Aplikasi, Yogyakarta: Teras, 2009.

W.S. Wingkel Bimbingan dan Konseling di Institusi Pendidikan, Jakarta: Gramedia, 1997

Wanda Esa Adi Wibowo, Upaya Mengatasi Perilaku Membolos Sekolah Melalui Konseling Individual Dengan Pendekatan Behavior Teknik Kontrak Perilaku (Penanganan Kasus Pada Siswa SMP Negeri 4 Rembang). Skripsi Fakultas Ilmu Pendidikan - Bimbingan dan Konseling, S1 Universitas Negeri Semarang.

Wawancara Guru BK SMP Diponegoro Depok, Sleman, Yogyakarta pada Hari Senin, 29 Agustus 2016. 
https://ejournal.radenintan.ac.id/index.php/konseli 